\title{
Phenolic Compounds from An Algerian Endemic Species of Hypochaeris laevigata var. hipponensis and Investigation of Antioxidant Activities
}

\author{
Nabila Souilah ${ }^{1,2}$, Zain Ullah ${ }^{3}(0)$, Hamdi Bendif ${ }^{4,5}$, Kamel Medjroubi ${ }^{2}(0)$, Tahar Hazmoune ${ }^{1}$,

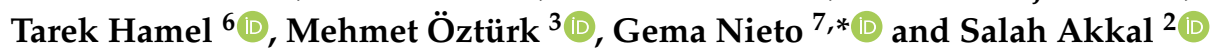 \\ 1 Laboratory of Optimization of Agricultural Production in Sub-Humid Zones (LOPAZS), Faculty of Science, \\ University of Skikda, Skikda 21000, Algeria; souilah_n_phyto@hotmail.fr (N.S.); \\ hazmoune_tahar@yahoo.fr (T.H.) \\ 2 Laboratory of Valorization of Natural Resources, Bioactive Molecules and Physicochemical and Biological \\ Analyzes Department of Chemistry, Faculty of Exact Sciences, University of Constantine 1, Constantine \\ 25000, Algeria; medjroubi@yahoo.fr (K.M.); salah4dz@yahoo.fr (S.A.) \\ 3 Department of Chemistry, Faculty of Sciences, University of Muğla Sitki Koçman, Muğla 48000, Turkey; \\ zainaup614@yahoo.com (Z.U.); mehmetozturk@mu.edu.tr (M.Ö.) \\ 4 Department of Natural Sciences and Life, Faculty of Science, University of M'sila, M'sila 28000, Algeria; \\ hamdi.bendif@univ-msila.dz \\ 5 Laboratoire d'ethnobotanique et des substances naturelles, Département des sciences naturelles, Ecole \\ Normale Supérieure (ENS), Kouba, BP 92 Kouba, Algiers 16308, Algeria \\ 6 Department of Natural Sciences and Life, Faculty of Science, University of Badji Mokhtar, Annaba 23000, \\ Algeria; tarek_hamel@yahoo.fr \\ 7 Department of Food Technology, Food Science and Nutrition, Faculty of Veterinary Sciences, Regional \\ Campus of International Excellence "Campus Mare Nostrum", Espinardo, 30071 Murcia, Spain \\ * Correspondence: gnieto@um.es; Tel.: +34-868889694
}

Received: 14 February 2020; Accepted: 12 April 2020; Published: 16 April 2020

\begin{abstract}
Hypochaeris laevigata var. hipponensis (Asteraceae) is an endemic plant from Algeria. In the current study, we analyzed for the first time its chemical composition, especially phenolic constituents of dichloromethane (DCM), ethyl acetate (EA), and n-butanol $(\mathrm{BuOH})$ fractionsof the aerial parts of Hypochaeris laevigata var. hipponensis by liquid chromatography-mass spectrometry (LC-MS/MS). The number of phenolic compounds detected in DCM, EA, and $\mathrm{BuOH}$ fractions were found to be 9, 20, and 15, respectively. More specifically, 12 phenolic acids were detected. Among them, quinic acid, chlorogenic acid, and caffeic acid were the most abundant ones. Meanwhile, only seven flavonoids were detected. Among them, rutin, apigetrin, and isoquercitrin were the major ones. We also determined the total phenolic and flavonoid contents, and fraction EA showed the highest values, followed by $\mathrm{BuOH}$, and DCM fractions. Furthermore, the antioxidant action was dictated by five methods and the tested plant fractions demonstrated a noteworthy antioxidant action.
\end{abstract}

Keywords: Hypochaeris laevigata var. hipponensis; Asteraceae; phenolic compounds; antioxidants activities; LC-MS/MS

\section{Introduction}

A large number of medicinal and aromatic plants grow spontaneously in the Edough Peninsula, such as plants of family Asteraceae which are rich in phenolic compounds, volatile oils, and other bioactive compounds. It is fundamental to extend the knowledge of the chemical composition of some plants of this family [1]. 
According to Stebbins [2], Hypochaeris is a smallgenusof the Asteraceae family, which contains about 50 species. On the other, the genus of Hypochoaeris contains 100 species, the majority of which are native to South America. The species of Hypochaeris laevigata var. hipponensis is a perennial plant with a bitter root, endemic to Algeria, but very common everywhere, and on the coast usually develops on wet rocks [3] and is used as a salad by the local population of Sérraidi.

Nowadays, no studies have been conducted regarding the phytochemicalcomposition of Hypochaeris laevigata var. hipponensis, except that of Jamunaet al. [4] who studiedthe composition of the species $H$. radicata and reported the presence of alkaloids, flavonoids, glycosides, cardiac glycosides, phenols, resins, saponins, steroids, tannins, terpenoids, and triterpenoids. Hypochaeris radicata is medically important and has anti-inflammatory, anticancer, antioxidant [5], antibacterial [6], antifungal [7] properties, and antidiuretics. It is used for the treatment of jaundice, rheumatism, dyspepsia, constipation, hypoglycemia, and kidney problems in the traditional medicinal practice of Tamil Nadu, India [8]. However, no scientific validation has been made for this species for medicinal purposes.

The aim of the present work was to study the chemical composition of Hypochaeris laevigata var. hipponensis, which is an endemic species from Algeria that has not been reported before, and to evaluate the phenolic compounds of the plant by the liquid chromatography-mass spectrometry (LC-MS/MS) technique and its antioxidant activities.

\section{Materials and Methods}

\subsection{Plant Material and Extraction Method}

A sample of the whole plant (Hypochaeris laevigata var. hipponensis) iscollected in full bloom in Sérraïdi (Annaba), in northeastern Algeria in May 2015 (Figure 1). The plant was identified by Dr. Tarek Hamel, Lecturer at the Department of Plant Biology and Environment, Badji Mokhtar University (Annaba, Algeria). A reference specimen was deposited in the herbarium of the laboratory under the reference code: ChifaDZUMCAPBC000038.

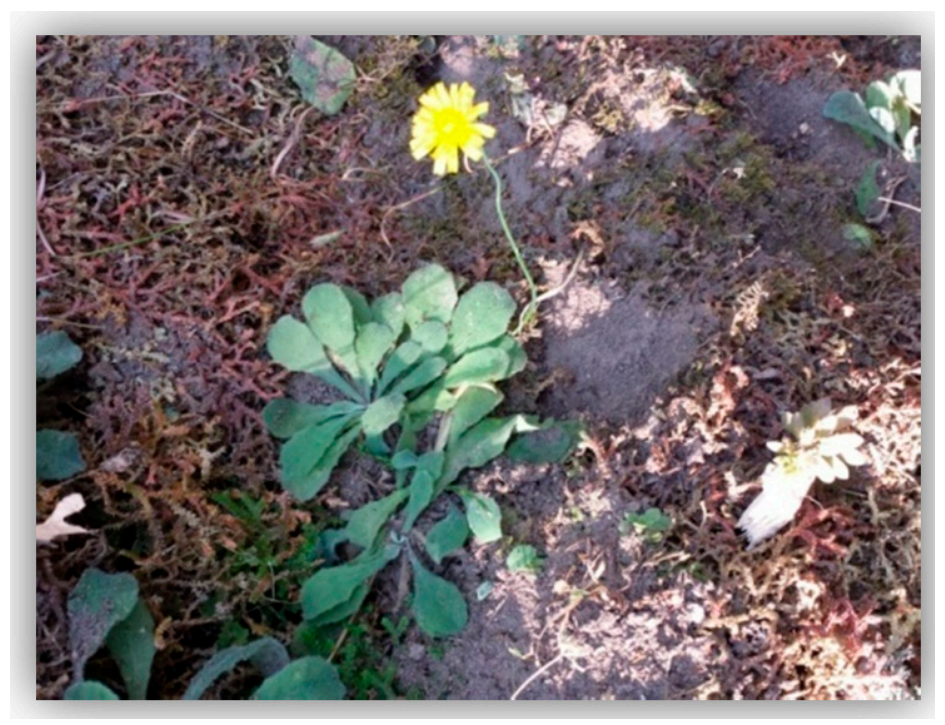

Figure 1. The plant of Hypochaeris laevigata var. hipponensis.

The aerial part of the plant $(800 \mathrm{~g})$ was dried in the shade at room temperature in a ventilated place, cut into small pieces and macerated in a mixture of methanol/water $(70 / 30, v / v)$ at a ratio of 1:10 $(w / v)$ for $24 \mathrm{~h}$ with a constant stirring speed of $200 \mathrm{rpm}$, at room temperature. The suspension was then filtered on whatman paper. The extraction is repeated three times till exhaustion, then the solvent was evaporated at $40^{\circ} \mathrm{C}$ using Rota Vapor (Büchi R-200, Aachen, Germany) to afford 3.73\% of crude extract. 
The crude extract was dissolved in $90 \%$ aqueous methanol for fractionation with different solvents such as dichloromethane (DCM), ethyl acetate (EA) and n-butanol (BuOH). Briefly, first fractionation was carried out with $100 \mathrm{~mL}$ DCM three times. DCM fraction was collected and evaporated under reduced pressure to give a semi-solid paste. Then, the residual aqueous phase of dichloromethane was further fractionated with $\mathrm{EA}$ and $\mathrm{BuOH}$ solvents. The resulting fractions were evaporated to dryness. Theyields of DCM, EA, and BuOHfractionswerefound to be $1.09 \%, 0.79 \%$, and $1.63 \%$, respectively. Dried fractions were dissolved in methanol and kept at a temperature of $4{ }^{\circ} \mathrm{C}$ for further analysis.

\subsection{Preparation of Standards}

The standard stock solutions were prepared in methanol $(50 \mu \mathrm{g} / \mathrm{mL})$ except hesperidin and isoquercitrin that were dissolved in dimethyl formamide $(50 \mu \mathrm{g} / \mathrm{mL})$. From the stock solutions, a number of working solutions were prepared by appropriate dilution in methanol. All solutions were stored in a refrigerator at $4{ }^{\circ} \mathrm{C}$ until analysis.

\subsection{LC-MS/MS Analysis}

The LC-MS analyses of phenolic compounds were performed using a Nexera model Shimadzu UHPLC coupled to a tandem MS instrument. The liquid chromatography was equipped with LC30AD binary pumps, CTO-10ASvp column oven, DGU-20A3R degasser and SIL-30AC autosampler. The chromatographic separation was performed on an RP-C18 Inertsil ODS-4 (100 mm $\times 2,1 \mathrm{~mm}, 2 \mu \mathrm{m})$ analytical column. Reversed-phase ultrahigh performance liquid chromatography was optimized to achieve optimum separation for 37 phytochemical compounds and to overcome the suppression effects. The column temperature was fixed at $35^{\circ} \mathrm{C}$. The elution gradient consisted of eluent $\mathrm{A}$ (water, $10 \mathrm{mM}$ ammonium formate and $0.1 \%$ formic acid) and eluent $\mathrm{B}$ (acetonitrile). The following gradient elution program was applied: $5 \%-20 \%$ B (0-10 min), 20\% B (10-22 min), 20\%-50\% B (22-36 min), 95\% B (36-40 $\mathrm{min}), 5 \% \mathrm{~B}(40-50 \mathrm{~min})$. The solvent flow rate was maintained at $0.25 \mathrm{~mL} / \mathrm{min}$ and injection volume was settled as $4 \mu \mathrm{L}$.

MS detection was performed using a Shimadzu brand LCMS 8040 model tandem mass spectrometer equipped with an ElectroSpray Ionization (ESI) source operating in negative ion mode. LC-ESI-MS/MS data was collected and shipped by LabSolutions Software (Shimadzu) software. Multiple reaction monitoring (MRM) was used to quantify it. The working conditions of the mass spectrometer were passed as interface temperature, $350{ }^{\circ} \mathrm{C}$; DL temperature, $250{ }^{\circ} \mathrm{C}$; temperature of the thermal block, $400^{\circ} \mathrm{C}$; nebulizationgas flow (nitrogen), $3 \mathrm{~L} / \mathrm{min}$; and drying gas stream (nitrogen), $15 \mathrm{~L} / \mathrm{min}$. Quantification of the target compounds was performed after optimizing the acquisition parameters (Table 1).

Table 1. HPLC-MS/MS acquisition parameters used for the analysis of the 37 marker compounds in the extracts of Hypochaerislaevigata var. hipponensis.

\begin{tabular}{ccccccc}
\hline No. & Compounds & $\begin{array}{c}\text { Retention } \\
\text { Time }(\mathbf{m i n})\end{array}$ & $\begin{array}{c}\text { Scan } \\
\text { Type }\end{array}$ & $\begin{array}{c}\text { Polarity or } \\
\text { (ESI Mode) }\end{array}$ & $\begin{array}{c}\text { Precursor Ion } \\
{[\mathbf{M}-\mathbf{H}]^{-}(\mathbf{m} / \mathbf{z})}\end{array}$ & $\begin{array}{c}\text { MS }^{2} \text { Fragments or } \\
\text { Product Ions }(\mathbf{m} / \mathbf{z})\end{array}$ \\
\hline 1 & Quinic acid & 1.13 & MRM & Negative & 190.95 & $85.3-93.3$ \\
\hline 2 & Malic acid & 1.23 & MRM & Negative & 133.00 & $115.2-71.3$ \\
\hline 3 & Fumaric acid & 1.48 & MRM & Negative & 115.00 & 71.4 \\
\hline 4 & Gallic acid & 3.00 & MRM & Negative & 168.85 & $125.2-79.2$ \\
\hline 5 & Protocatechic acid & 4.93 & MRM & Negative & 152.95 & 108.3 \\
\hline 7 & Pyrocatechol & 6.48 & MRM & Negative & 109.00 & $108.35-91.3$ \\
\hline 8 & Chlorogenic acid & 7.13 & MRM & Negative & 353.15 & 191.2 \\
\hline 9 & 4-OH-Benzoic acid & 7.39 & MRM & Negative & 136.95 & $93.3-65.3$ \\
\hline
\end{tabular}


Table 1. Cont

\begin{tabular}{|c|c|c|c|c|c|c|}
\hline No. & Compounds & $\begin{array}{l}\text { Retention } \\
\text { Time (min) }\end{array}$ & $\begin{array}{l}\text { Scan } \\
\text { Type }\end{array}$ & $\begin{array}{l}\text { Polarity or } \\
\text { (ESI Mode) }\end{array}$ & $\begin{array}{l}\text { Precursor Ion } \\
{[\mathrm{M}-\mathrm{H}]^{-}(\mathrm{m} / \mathrm{z})}\end{array}$ & $\begin{array}{l}\mathrm{MS}^{2} \text { Fragments or } \\
\text { Product Ions }(\mathrm{m} / \mathrm{z})\end{array}$ \\
\hline 10 & Caffeic acid & 8.80 & MRM & Negative & 178.95 & $135.2-134.3$ \\
\hline 11 & Syringic acid & 9.02 & MRM & Negative & 196.95 & $182.2-167.3$ \\
\hline 12 & Vanillin & 10.87 & MRM & Negative & 151.00 & $1363-92.2$ \\
\hline 13 & Salicylic acid & 11.16 & MRM & Negative & 136.95 & $93.3-65.3$ \\
\hline 14 & $p$-Coumaric acid & 11.53 & MRM & Negative & 162.95 & 119.3-93.3 \\
\hline 15 & Rutin & 12.61 & MRM & Negative & 609.05 & $300.1-271.1$ \\
\hline 16 & Ferulic acid & 12.62 & MRM & Negative & 192.95 & 178.3 \\
\hline 17 & Sinapic acid & 12.66 & MRM & Negative & 222.95 & $208.3-149.2$ \\
\hline 18 & Hesperidin & 12.67 & MRM & Negative & 609 & 301.1 \\
\hline 19 & Isoquercitrin & 13.42 & MRM & Negative & 463.00 & $300.1-271.1$ \\
\hline 20 & Rosmarinic acid & 14.54 & MRM & Negative & 359.00 & 161.2-197.2 \\
\hline 21 & Nicotiflorin & 14.68 & MRM & Negative & 593.05 & $285.1-255.2$ \\
\hline 22 & $\alpha$-Coumaric acid & 15.45 & MRM & Negative & 162.95 & $119.4-93.3$ \\
\hline 23 & Rhoifolin & 16.11 & MRM & Negative & 577.05 & $269.2-211.1$ \\
\hline 24 & Quercitrin & 16.41 & MRM & Negative & 447.15 & $301.1-255.1$ \\
\hline 25 & Apigetrin & 16.59 & MRM & Negative & 431.00 & $268.2-239.2$ \\
\hline 26 & Coumarin & 17.40 & MRM & Negative & 147.05 & $91.0-103.2$ \\
\hline 27 & Myricetin & 18.72 & MRM & Negative & 317.00 & $179.2-151.3$ \\
\hline 28 & Fisetin & 19.30 & MRM & Negative & 284.95 & $135.2-121.3$ \\
\hline 29 & Cinnamic acid & 25.61 & MRM & Negative & 147.00 & $103.15-77.3$ \\
\hline 30 & Liquiritigenin & 25.62 & MRM & Negative & 254.95 & $119.3-135.1$ \\
\hline 31 & Quercetin & 28.17 & MRM & Negative & 300.90 & $151.2-179.2$ \\
\hline 32 & Luteolin & 28.27 & MRM & Negative & 284.75 & $133.2-151.2$ \\
\hline 33 & Naringenin & 30.68 & MRM & Negative & 270.95 & $151.2-119.3$ \\
\hline 34 & Apigenin & 31.43 & MRM & Negative & 268.95 & $117.3-151.2$ \\
\hline 35 & Hesperetin & 31.76 & MRM & Negative & 300.95 & $164.2-136.2$ \\
\hline 36 & Kaempferol & 31.88 & MRM & Negative & 284.75 & $255.1-117.3$ \\
\hline 37 & Chrysin & 36.65 & MRM & Negative & 252.95 & $143.3-119.4$ \\
\hline
\end{tabular}

A complete LC-MS/MS method was optimized and validated for the quantification of 37 phytochemical fingerprint compounds (17 flavonoids, 15 phenolic acids, 3 non-phenolic organic acids, 1 benzopyrene and 1 phenolic aldehyde) on the species studied. The performance characteristics of the method were determined using standard solutions as well as enriched and non-enriched samples. In this context, the developed method has been fully validated in terms of linearity, accuracy (recovery), inter-day and intra-day precision (repeatability), detection and quantification limits (LOD/LOQ) and uncertainty relative standards ( $\mathrm{U} \%$ at $95 \%$ confidence level $[\mathrm{k}=2]$ ) (Table 2, Figure 2$)$. The dry extracts were prepared at a concentration of $1 \mathrm{mg} / \mathrm{mL}$ and filtered with a $0.2 \mu \mathrm{m}$ syringe filter prior to LC-MS/MS analysis. Each sample was analyzed three times. 
Table 2. Concentration range, linearity $\left(\mathrm{R}^{2}\right)$, Limits of Detection (LODs), Limits of Quantification (LOQs) and percentages of recoveries of the analysed 37 compounds by LC-MS/MS.

\begin{tabular}{|c|c|c|c|c|c|c|c|c|c|c|}
\hline \multirow{3}{*}{$\begin{array}{l}\mathbf{N} \\
1\end{array}$} & \multirow{3}{*}{$\begin{array}{l}\text { Compounds } \\
\text { Quinic acid }\end{array}$} & \multirow{3}{*}{$\begin{array}{c}\begin{array}{c}\text { Conc. Range } \\
\text { (Linearity Range) } \\
(\mu \mathrm{g} / \mathrm{mL})\end{array} \\
0.250-10\end{array}$} & \multirow{3}{*}{$\begin{array}{c}\mathbf{R}^{2} \\
0.996\end{array}$} & \multirow{3}{*}{$\begin{array}{c}\begin{array}{c}\text { LOD } \\
(\mu \mathrm{g} / \mathrm{mL})\end{array} \\
0.075 \\
\end{array}$} & \multirow{3}{*}{$\begin{array}{c}\begin{array}{c}\text { LOQ } \\
(\mu \mathrm{g} / \mathrm{mL})\end{array} \\
0.079 \\
\end{array}$} & \multirow{3}{*}{$\begin{array}{c}\begin{array}{c}\text { Inter-Day } \\
(n=3)\end{array} \\
\text { RSD (\%) }\end{array}$} & \multirow{3}{*}{$\begin{array}{c}\begin{array}{c}\text { Intra-Day } \\
(n=3)\end{array} \\
\text { RSD (\%) }\end{array}$} & \multirow{2}{*}{\multicolumn{2}{|c|}{$\begin{array}{c}\text { Recovery \% }(n=3) \\
\text { Inter-Day Intra-Day }\end{array}$}} & \multirow{3}{*}{$\begin{array}{l}\text { U (\%) } \\
0.0082 \\
\end{array}$} \\
\hline & & & & & & & & & & \\
\hline & & & & & & & & 100.28 & 98.77 & \\
\hline 2 & Malic acid & $0.250-10$ & 0.999 & 0.055 & 0.067 & 0.477 & 0.527 & 101.26 & 99.83 & 0.0113 \\
\hline 3 & Fumaric acid & $0.10-5$ & 0.997 & 0.028 & 0.034 & 0.536 & 0.460 & 99.74 & 99.86 & 0.0124 \\
\hline 4 & Gallic acid & $0.250-10$ & 0.998 & 0.095 & 0.106 & 1.601 & 01.443 & 100.00 & 100.45 & 0.0282 \\
\hline 5 & Protocatechic acid & $0.100-5$ & 0.995 & 0.028 & 0.031 & 1.236 & 1.296 & 99.40 & 101.07 & 0.0411 \\
\hline 6 & Pyrocatechol & $1-20$ & 0.996 & 0.261 & 0.278 & 1.313 & 1.339 & 99.98 & 99.93 & 0.0235 \\
\hline 7 & Chlorogenic acid & $0.025-1$ & 0.998 & 0.006 & 0.008 & 0.058 & 0.076 & 100.80 & 99.96 & 0.0069 \\
\hline 8 & 4-OH-Benzoic acid & $0.250-10$ & 0.998 & 0.033 & 0.038 & 1.284 & 1.538 & 99.66 & 100.05 & 0.0289 \\
\hline 9 & Vanillic acid & $0.1-20$ & 0.999 & 0.122 & 0.139 & 0.528 & 0.619 & 100.09 & 104.09 & 0.0508 \\
\hline 10 & Caffeic acid & $0.025-1$ & 0.998 & 0.018 & 0.022 & 1.454 & 1.469 & 100.91 & 98.82 & 0.0354 \\
\hline 11 & Syringic acid & $0.1-20$ & 0.996 & 0.021 & 0.233 & 1.049 & 1.345 & 99.92 & 99.97 & 0.0238 \\
\hline 12 & Vanillin & $0.250-10$ & 0.998 & 0.044 & 0.053 & 0.696 & 0.793 & 99.67 & 99.61 & 0.0280 \\
\hline 13 & Salicylic acid & $0.025-1$ & 0.989 & 0.005 & 0.006 & 1.016 & 1.242 & 100.98 & 99.01 & 0.0329 \\
\hline 14 & $p$-Coumaric acid & $0.025-1$ & 0.992 & 0.007 & 0.009 & 1.820 & 1.727 & 100.61 & 101.22 & 0.0516 \\
\hline 15 & Rutin & $0.025-1$ & 0.997 & 0.005 & 0.006 & 0.473 & 0.624 & 100.99 & 98.01 & 0.0159 \\
\hline 16 & Ferulic acid & $0.250-10$ & 0.997 & 0.036 & 0.042 & 0.708 & 0.619 & 99.98 & 100.28 & 0.0494 \\
\hline 17 & Sinapic acid & $0.250-10$ & 0.992 & 0.078 & 0.086 & 1.446 & 1.517 & 100.16 & 99.96 & 0.0281 \\
\hline 18 & Hesperidin & $0.025-1$ & 0.998 & 0.003 & 0.004 & 0.945 & 1.126 & 101.73 & 101.26 & 0.0262 \\
\hline 19 & Isoquercitrin & $0.025-1$ & 0.999 & 0.005 & 0.006 & 0.682 & 0.515 & 100.59 & 100.72 & 0.0133 \\
\hline 20 & Rosmarinic acid & $0.100-5$ & 0.994 & 0.006 & 0.008 & 2.014 & 1.751 & 99.20 & 103.43 & 0.0713 \\
\hline 21 & Nicotiflorin & $0.100-5$ & 0.991 & 0.022 & 0.025 & 0.737 & 0.875 & 102.55 & 100.97 & 0.0276 \\
\hline 22 & $\alpha$-Coumaric acid & $0.025-1$ & 0.999 & 0.024 & 0.031 & 2.730 & 2.566 & 98.34 & 99.06 & 0.0513 \\
\hline 23 & Rhoifolin & $0.100-5$ & 0.999 & 0.023 & 0.027 & 0.747 & 1.528 & 101.04 & 101.73 & 0.0941 \\
\hline 24 & Quercitrin & $0.100-5$ & 0.999 & 0.022 & 0.025 & 1.528 & 2.320 & 99.72 & 100.62 & 2.0079 \\
\hline 25 & Apigetrin & $0.025-1$ & 0.993 & 0.005 & 0.006 & 1.797 & 1.607 & 101.39 & 100.41 & 0.0597 \\
\hline 26 & Coumarin & $1-20$ & 0.994 & 0.208 & 0.228 & 1.306 & 1.239 & 99.94 & 100.08 & 0.0237 \\
\hline 27 & Myricetin & $0.250-10$ & 0.999 & 0.053 & 0.057 & 0.652 & 0.711 & 99.98 & 100.04 & 0.0126 \\
\hline 28 & Fisetin & $0.250-10$ & 0.991 & 0.054 & 0.051 & 0.557 & 0.820 & 99.87 & 100.03 & 0.0148 \\
\hline 29 & Cinnamic acid & 5-20 & 0.996 & 0.821 & 0.859 & 0.648 & 0.816 & 100.05 & 99.92 & 0.0143 \\
\hline 30 & Liquiritigenin & $0.025-1$ & 0.996 & 0.005 & 0.006 & 1.849 & 1.738 & 100.33 & 99.95 & 0.0341 \\
\hline 31 & Quercetin & $0.100-5$ & 0.990 & 0.023 & 0.028 & 1.589 & 1.360 & 98.47 & 100.10 & 0.0543 \\
\hline 32 & Luteolin & $0.025-1$ & 0.997 & 0.005 & 0.006 & 0.575 & 0.696 & 100.77 & 99.52 & 0.0174 \\
\hline 33 & Naringenin & $0.025-1$ & 0.995 & 0.005 & 0.006 & 2.054 & 2.019 & 99.88 & 101.00 & 0.0521 \\
\hline 34 & Apigenin & $0.025-1$ & 0.990 & 0.005 & 0.006 & 2.304 & 2.204 & 101.44 & 101.33 & 0.0650 \\
\hline 35 & Hesperetin & $0.025-1$ & 0.997 & 0.005 & 0.006 & 3.209 & 2.605 & 98.85 & 99.43 & 0.0562 \\
\hline 36 & Kaempferol & $1-20$ & 0.992 & 0.206 & 0.214 & 1.436 & 1.070 & 99.97 & 99.85 & 0.0209 \\
\hline 37 & Chrysin & $0.02-1$ & 0.993 & 0.005 & 0.006 & 0.490 & 0.630 & 100.33 & 100.43 & 2.0083 \\
\hline
\end{tabular}

RSD \%: relative standard deviation. U (\%): uncertainty Percent at 95\% confidence level $(k=2)$.

\subsection{Quantification of Total Phenols}

The total phenolic content was evaluated according to the method described by Li et al. [9]. Thereby $1.5 \mathrm{~mL}$ of the Folin-Ciocalteu reagent previously diluted ten times with distilled water was added to $300 \mu \mathrm{L}$ of the extract. After $4 \mathrm{~min}, 1.2 \mathrm{~mL}$ of $7.5 \%$ sodium carbonate $\left(\mathrm{Na}_{2} \mathrm{CO}_{3}\right)$ was poured onto the solution. The samples were placed in the dark. After $2 \mathrm{~h}$, the results were read on a spectrophotometer at $750 \mathrm{~nm}$, the concentration of total phenols is deduced from a calibration curve established with gallic acid and the results were expressed in $\mathrm{mg}$ of gallic acid equivalent per $\mathrm{g}$ dried extract (mg GAE/ g extract). 


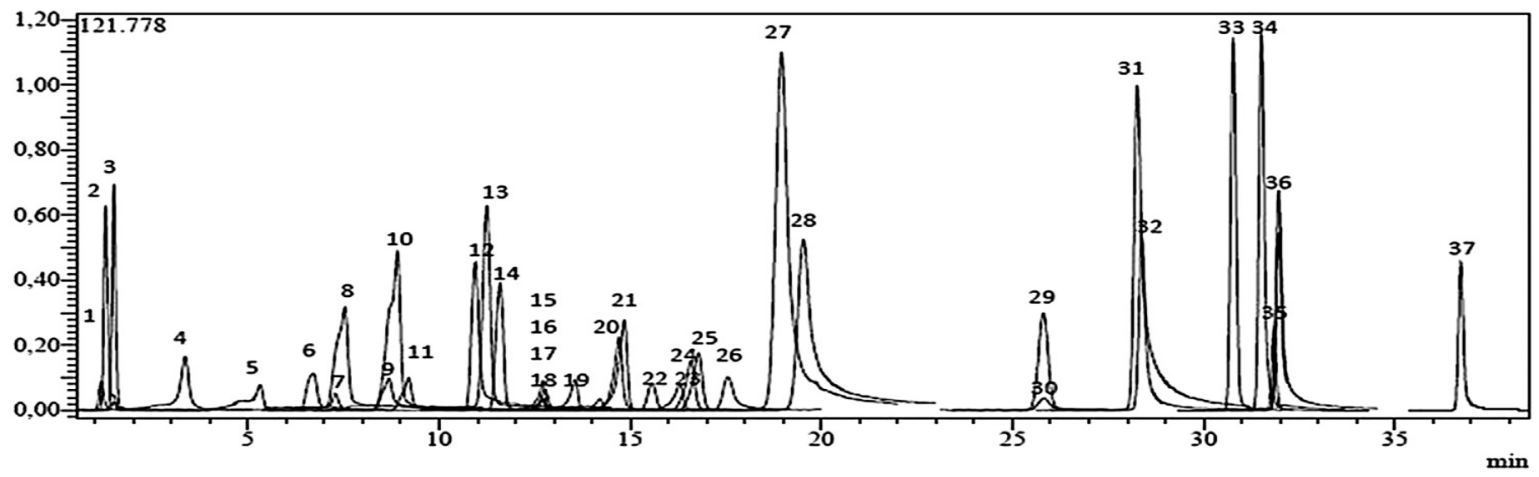

Figure 2. TIC chromatogram of the standards mixture $(1 \mu \mathrm{g} / \mathrm{mL})$ analyzed by the LC-MS/MS. Legend: (1) quinic acid, (2) malic acid, (3) fumaric acid, (4) gallic acid, (5) protocatechic acid, (6) pyrocatechol, (7) chlorogenic acid, (8) 4-OH-benzoic acid, (9) vanillic acid, (10) caffeic acid, (11) syringic acid, (12) vanillin, (13) salicylic acid, (14) $p$-coumaric acid, (15) rutin, (16) ferulic acid, (17) sinapic acid, (18) hesperidin, (19) isoquercitrin, (20) rosmarinic acid, (21) nicotiflorin, (22) $\alpha$-coumaric acid, (23) rhoifolin, (24) quercitrin, (25) apigetrin, (26) coumarin, (27) myricetin, (28) fisetin, (29) cinnamic acid, (30) liquiritigenin, (31) quercetin, (32) luteolin, (33) naringenin, (34) apigenin, (35) hesperetin, (36) kaempferol and (37) chrysin.

\subsection{Quantification of Flavonoids}

The content of total flavonoids was determined according to the method described by Djeridane et al. [10]. Thereby, the extract was mixed ( $500 \mu \mathrm{L})$ with $500 \mu \mathrm{L}$ of $2 \%$ aluminum chloride. The absorbance of the mixture is measured at $430 \mathrm{~nm}$, after $10 \mathrm{~min}$ of incubation. The flavonoid concentrations were expressed in mg equivalent quercetin per g dried extract (mg QE/g extract) with reference to a calibration curve.

\subsection{Antioxidant Activities}

\subsubsection{Evaluation of Antioxidant Activity by $\beta$-Carotene Bleaching Test}

The antioxidant activity of the extracts was evaluated using the $\beta$-carotene-linoleic acid system described by Miller [11] with a slight modification. Dissolve $0.5 \mathrm{mg}$ of $\beta$-carotene in $1 \mathrm{~mL}$ of chloroform. The solution obtained was introduced into a flask containing a mixture of $25 \mu \mathrm{L}$ of linoleic acid and $200 \mathrm{mg}$ of Tween 40. After evaporation of the chloroform under vacuum, $100 \mathrm{~mL}$ of distilled water saturated with oxygen were added by vigorous stirring. From this new solution, $4 \mathrm{~mL}$ was transferred to different test tubes containing different concentrations of the sample in ethanol. As soon as the emulsion was added to each tube, the absorbance of the zero time was measured at $470 \mathrm{~nm}$, using a spectrophotometer. The emulsion system was incubated for $2 \mathrm{~h}$ at $50^{\circ} \mathrm{C}$. A negative control, free of $\beta$-carotene, was prepared for background subtraction. The bleaching rate (R) of $\beta$-carotene was calculated according to the following equation: $\mathrm{R}=\ln _{\mathrm{a} / \mathrm{b}} / \mathrm{t}$. the natural $\log$, $\mathrm{a}$ is the absorbance at zero time, $b$ is the absorbance at time $t(120 \mathrm{~min})$. Antioxidant activity (AA) was calculated in terms of percent inhibition versus control, using the following equation:

$$
\% \text { inhibition }=[R \text { control }-R \text { sample } / R \text { control }] \times 100 .
$$

Quercetin, BHT, and $\alpha$-tocopherol have been used as antioxidant standards for the comparison.

\subsubsection{DPPH Free Radical Scavenging Test}

The anti-radical activity against DPPH of the studied extracts was measured by the DPPH test described by Blois [12] with a slight modification. Briefly a $0.1 \mathrm{mM}$ solution of DPPH in methanol was prepared and $4 \mathrm{~mL}$ of this prepared solution were added to $1 \mathrm{~mL}$ of sample solutions in methanol at 
different concentrations. After $30 \mathrm{~min}$ of incubation in the dark at room temperature, the absorbance is measured at $517 \mathrm{~nm}$. Lower absorbance of the reaction mixture indicated greater free radical scavenging activity. The antioxidant activity was expressed as a percentage of DPPH radical inhibition, and calculated from the following equation:

$$
\% \text { inhibition }=[\text { A control }- \text { A sample } / \text { A control }] \times 100 .
$$

The $\mathrm{IC}_{50}$ value (the inhibitory concentration of the extract necessary to decrease the initial concentration of the DPPH radical at 50\%) was calculated from the percentage plot of the trapping effect of the different concentrations of each extract [13]. We deduced the anti-radical activity of the extracts by calculating the inverse of the $\mathrm{IC}_{50}$ values found [14], by the following formula: $\mathrm{ARA}=$ $1 / \mathrm{IC}_{50}$. Quercetin, $\mathrm{BHT}$, and $\alpha$-tocopherol have been used as antioxidant standards for the comparison of activity.

\subsubsection{ABTS Radical Cation Reduction Test}

The anti-radical activity against the radical $\mathrm{ABTS}^{+}$of the studied extracts was determined according to the method of Re et al. [15] with slight modification. In this test, the radical cation ABTS ${ }^{+}$ is generated by mixing $7 \mathrm{mM}$ ABTS in $\mathrm{H}_{2} \mathrm{O}$ and $2.45 \mathrm{mM}$ Potassium Persulfate. The mixture is then stored in the dark at room temperature for $12 \mathrm{~h}$. The oxidation of $\mathrm{ABTS}^{+}$started immediately, but the absorbance was not maximal and stable until more than $6 \mathrm{~h}$ had elapsed. The radical cation was stable in this form for more than 2 days with storage in the dark at room temperature. Before use, the $\mathrm{ABTS}^{+}$ solution was diluted with ethanol to obtain an absorbance of $0.700 \pm 0.02$ at $734 \mathrm{~nm}$. Then $2 \mathrm{~mL}$ of ABTS $^{+}$ solution was added to $1 \mathrm{~mL}$ of sample solution in ethanol at different concentrations $(5-50 \mathrm{mg} / \mathrm{mL})$. After $30 \mathrm{~min}$, the percent inhibition at $734 \mathrm{~nm}$ was calculated for each concentration based on a blank absorbance (methanol). The $\mathrm{ABTS}^{+}$scanning capability was calculated using the following equation:

$$
\% \text { inhibition }=[\text { Abs control }- \text { Abs sample } / \text { Abs control }] \times 100
$$

where the Abs controls are ABTS solution absorbance plus methanol, and the Abs sample is ABTS absorbance plus extract or standard. The $\mathrm{IC}_{50}$ value is calculated for each sample and compared with quercetin, BHT, and $\alpha$-tocopherol, which were used as antioxidant standards for activity comparison.

\subsubsection{Cupric Reducing Antioxidant Capacity (CUPRAC) Test}

The cupric reductive antioxidant capacity was determined according to the method of Apaket al. [16] with a slight modification. In each well, in a 96-well plate, $50 \mu \mathrm{L}$ of $10 \mathrm{mM} \mathrm{Cu}$ (II) solution, $50 \mu \mathrm{L}$ of $7.5 \mathrm{Mm}$ neocuprone and $60 \mu \mathrm{L}$ of $\mathrm{NH}_{4}$ Ac buffer $(1 \mathrm{M}, \mathrm{pH} 7.0)$ were added. $40 \mu \mathrm{L}$ extracts at different concentrations were added to the initial mixture to obtain the final volume of $200 \mu \mathrm{L}$. After $1 \mathrm{~h}$, the absorbance at $450 \mathrm{~nm}$ was recorded against a reagent blank using a 96-well microplate reader. The results were given as $A_{0.50}(\mu \mathrm{g} / \mathrm{mL})$, which corresponds to the concentration providing 0.500 absorbance. The concentration of the sample providing 0.50 absorbance $\left(\mathrm{A}_{0.50}\right)$ was calculated from the graph of the absorbance of cupric reductive antioxidant capacity. BHT and $\alpha$-tocopherol were used as antioxidant standards for comparing the activity.

\subsubsection{Ferrous Ions Chelating Test}

The chelating activity of the $\mathrm{Fe}^{2+}$ extracts was measured using Ferrin [17] with slight modifications. The extract solution ( $80 \mu \mathrm{L}$ dissolved in ethanol at different concentrations) was added to $40 \mu \mathrm{L}$ of $0.2 \mathrm{mM} \mathrm{FeCl}_{2}$. The reaction was initiated by the addition of $80 \mu \mathrm{L}$ of $0.5 \%$ ferene. The mixture was stirred vigorously and left at room temperature for $10 \mathrm{~min}$. After the mixture reached 
equilibrium, the absorbance was measured at $593 \mathrm{~nm}$. The chelating activity was calculated using the following equation:

$$
\% \text { of metal chelation activity }=[A \text { control }-A \text { sample } / A \text { control }] \times 100
$$

where A control is the absorbance of the sample-free control and A sample is the absorbance of the sample in the presence of the chelator. The concentration of extract providing $50 \%$ of metal chelation activity $\left(\mathrm{IC}_{50}\right)$ was calculated from the graph of the percentage of $\mathrm{Fe}^{2+}$ chelation effects relative to the concentration of extract. EDTA and quercetin were used as antioxidant standards for the comparison of the activity.

\subsection{Statistical Analysis}

All data of antioxidant activities tests were the average of three analyses. The data were recorded as mean \pm standard deviation. Significant differences between means were determined by student's- $t$ test and $p$ values $<0.05$ were considered as significant results.

\section{Results and Discussion}

\subsection{Analysis of LC-MS/MS}

According to the results of LC-MS/MS analysis, the analyzed extracts were rich in phenolic acids and flavonoids. A total of 12 phenolic acids (Gallic acid, protocatechic acid, chlorogenic acid, vanillic acid, caffeic acid, syringic acid, salicylic acid, ferulic acid, sinapicacid, rosmarinic acid, 4-OH-benzoic acid and $p$-coumaric acid), seven flavonoids (rutin, hesperidin, isoquercitrin, rhoifolin, quercitrin, apigetrin and apigenin), two non-phenolic organic acids (Quinic acid, malic acid), one phenolic aldehyde (vanillin), and one benzopyrone (coumarin)were identified in the analyzed plant samples(Table 3).

The ethylacetate fraction (EA) showed the highest values with the presence of 20 phenolic compounds (Figure 3), followed by n-butanol $(\mathrm{BuOH})$ and dichloromethane(DCM) fractions with 15 and nine phenolic compounds, respectively (Figures 4 and 5).

The LC-MS analysis of the ethyl acetate extract (EA)revealed the presence of quinic acid, chlorogenic acid, caffeic acid, ferulicacid, $p$-coumaric acid, syringic acid, and 4-OH-benzoic acid which showed the highest concentrations (9633.02, 2689.03, 1537.29, 1319.88, 1235.76, 1263.17, and $912.26 \mu \mathrm{g} / \mathrm{g}$ of extract, respectively). Meanwhile, rhoifolin, apigenin, rosmarinic acid, apigetrin, salicylic acid, hesperidin, quercitrin and isoquercitrin $(28.58,35.5,39.58,54.62,69.03,77.24,83.47,98.55 \mu \mathrm{g} / \mathrm{g}$ of extract, respectively) were found with the lowest values.

The phenolic compounds were reported to have a beneficial effect on health and can also be exploited for phyto-pharmaceutical applications because of their biological properties [18]. Among the main compounds found in our extracts, gallic acid is one of the most important phenolic compounds, due to its antineoplastic, bacteriostatic, anti-melanogenic, antioxidant, and anticancer properties [19]. However, chlorogenic, caffeic, and ferulic acids proved to have antioxidant and antimicrobial activities [18].

Whereas flavonoids can treat different diseases, such as viral, inflammatory, liver, allergic, thrombotic, and cancer [18-21], the flavonoids which we found in the plant were reported to have various biological activities. For example, rutin exhibited beneficial effects such as antioxidants, anti-allergic, antiviral, anti-inflammatory, anti-atherosclerosis by inhibiting platelet aggregation as well as anticancer activity. It has also been suggested to play a protective role in cardiovascular diseases and liver $[20,21]$. Meanwhile, apigetrin is a substance applied in the treatment of diabetes and cancer $[22,23]$. 


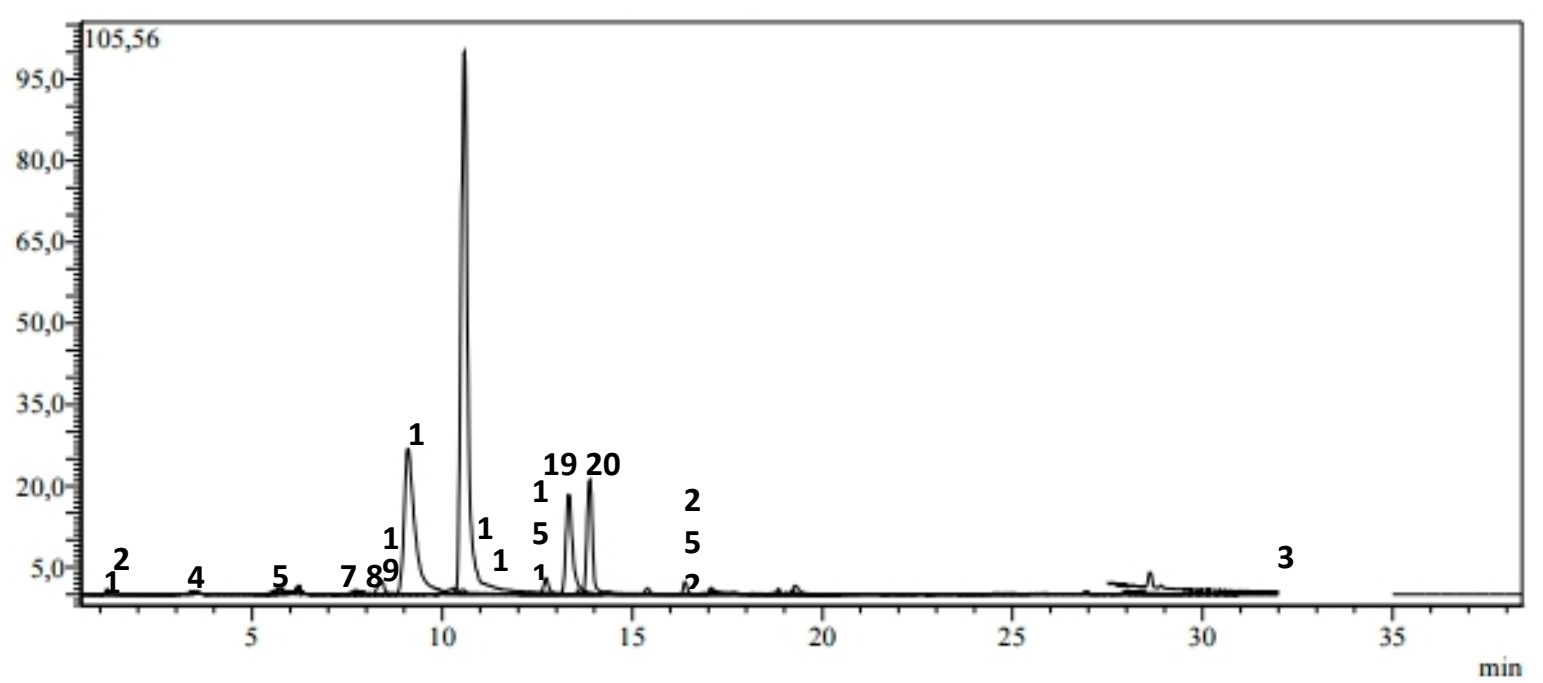

Figure 3. LC-MS/MS chromatogram of EA extract of H. laevigata var. hipponensis.

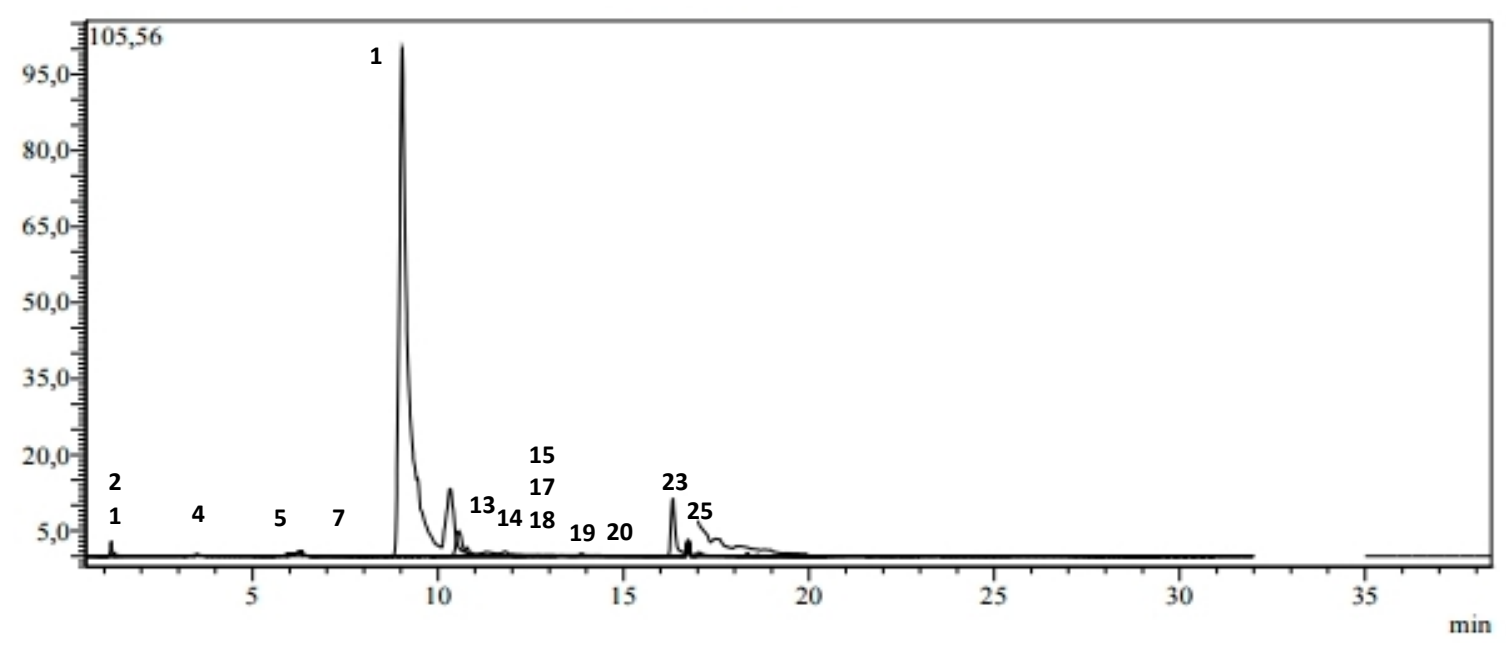

Figure 4. LC-MS/MS chromatogram of $\mathrm{BuOH}$ extract of H. laevigata var. hipponensis.

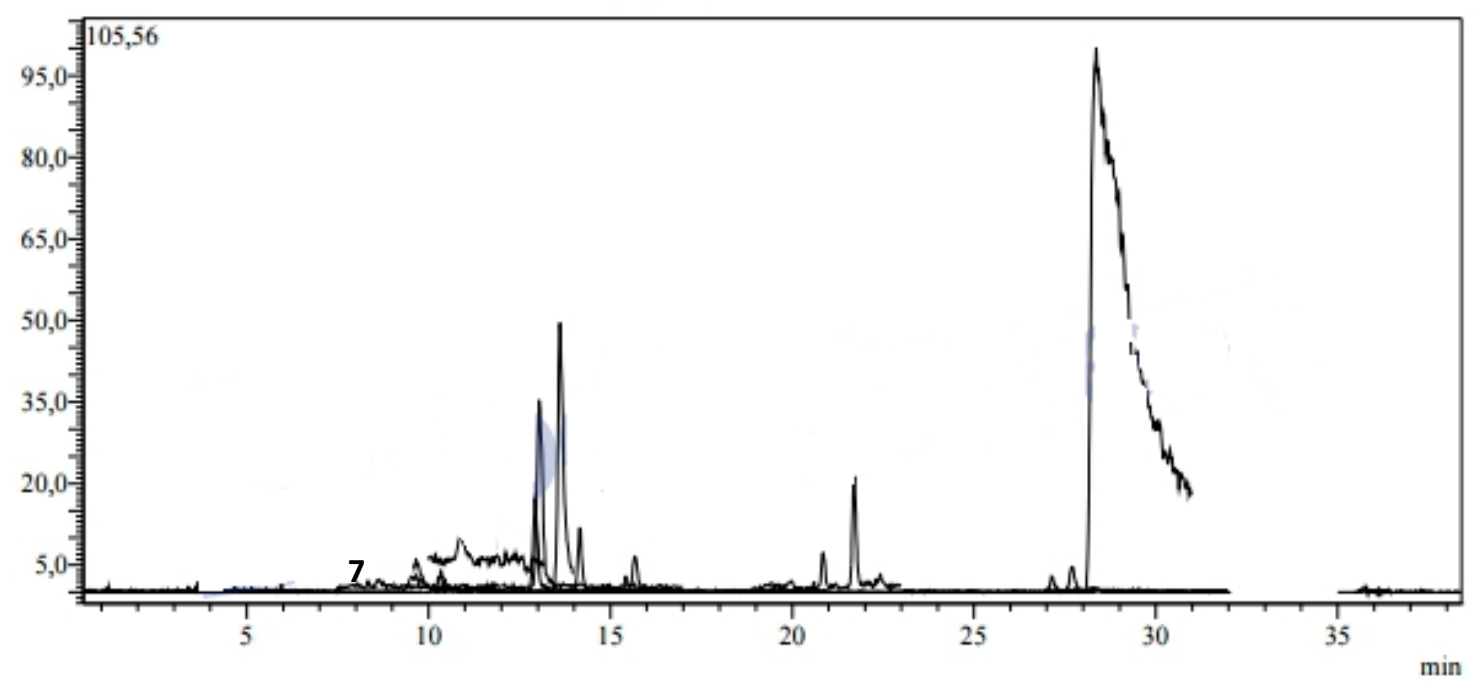

Figure 5. LC-MS/MS chromatogram of DCM extract of H. laevigata var. hipponensis. 
Table 3. Quantitative determination of 37 phenolic compounds in the extracts of Hypochaeris laevigata var. hipponensis ( $\mu \mathrm{g} / \mathrm{g}$ extract) by LC-MS/MS.

\begin{tabular}{|c|c|c|c|c|}
\hline $\mathbf{N}$ & Compounds & DCM & EA & $\mathrm{BuOH}$ \\
\hline 1 & Quinic acid & N.I & 9633.02 & $21,606.73$ \\
\hline 2 & Malic acid & N.I & 349.27 & 750.10 \\
\hline 3 & Fumaric acid & N.I & N.I & N.I \\
\hline 4 & Gallic acid & N.I & 223.26 & 115.09 \\
\hline 5 & Protocatechic acid & N.I & 547.25 & 54.77 \\
\hline 6 & Pyrocatechol & N.I & N.I & N.I \\
\hline 7 & Chlorogenic acid & 9.39 & 2689.03 & $11,956.23$ \\
\hline 8 & 4-OH-Benzoic acid & N.I & 912.26 & N.I \\
\hline 9 & Vanillic acid & 148.3 & 1027.7 & N.I \\
\hline 10 & Caffeic acid & 1.82 & 1537.29 & 98.47 \\
\hline 11 & Syringic acid & N.I & 1235.76 & N.I \\
\hline 12 & Vanillin & 58.32 & N.I & N.I \\
\hline 13 & Salicylic acid & 17.5 & 69.03 & 3.54 \\
\hline 14 & $p$-Coumaric acid & 10.38 & 1263.17 & 31.72 \\
\hline 15 & Rutin & N.I & 198.71 & 1348.25 \\
\hline 16 & Ferulicacid & 224.36 & 1319.88 & N.I \\
\hline 17 & Sinapic acid & N.I & N.I & 948.68 \\
\hline 18 & Hesperidin & N.I & 77.24 & 74.7 \\
\hline 19 & Isoquercitrin & N.I & 98.55 & 76.3 \\
\hline 20 & Rosmarinic acid & N.I & 39.58 & 12.49 \\
\hline 21 & Nicotiflorin & N.I & N.I & N.I \\
\hline 22 & $\alpha$-Coumaric acid & N.I & N.I & N.I \\
\hline 23 & Rhoifolin & N.I & 28.58 & 250.08 \\
\hline 24 & Quercitrin & N.I & 83.47 & N.I \\
\hline 25 & Apigetrin & N.I & 54.62 & 18.07 \\
\hline 26 & Coumarin & 1171.49 & N.I & N.I \\
\hline 27 & Myricetin & N.I & N.I & N.I \\
\hline 28 & Fisetin & N.I & N.I & N.I \\
\hline 29 & Cinnamic acid & N.I & N.I & N.I \\
\hline 30 & Liquiritigenin & N.I & N.I & N.I \\
\hline 31 & Quercetin & N.I & N.I & N.I \\
\hline 32 & Luteolin & N.I & N.I & N.I \\
\hline 33 & Naringenin & N.I & N.I & N.I \\
\hline 34 & Apigenin & 151.43 & 35.5 & N.I \\
\hline 35 & Hesperetin & N.I & N.I & N.I \\
\hline 36 & Kaempferol & N.I & N.I & N.I \\
\hline 37 & Chrysin & N.I & N.I & N.I \\
\hline
\end{tabular}

N.I: Not Identified.

\subsection{Total Phenolic and Flavonoid Contents}

The results of the total phenolic contents (Table 4) of the three extracts of H. laevigata var. hipponensis showed that the ethyl acetate (EA) and n-butanol (BuOH) extracts have the highest value with 202.86 \pm 14.64 and $200 \pm 10.93 \mathrm{GAE} / \mathrm{g}$ extract, respectively. Also, the total flavonoid content (Table 4$)$ of the $\mathrm{BuOH}$ extract $(46.76 \pm 0.36 \mathrm{QE} / \mathrm{g}$ of extract) was greater than that of EA and DCM extracts $(17.92 \pm 0.12$ and $16.28 \pm 0.16 \mathrm{QE} / \mathrm{g}$ extract, respectively).

Table 4. Total phenolic and flavonoid contents of the extracts of H. laevigata var. hipponensis.

\begin{tabular}{ccc}
\hline Extracts & Total Phenols $^{\mathbf{a}}$ & Flavonoids $^{\mathbf{b}}$ \\
\hline DCM & $184.07 \pm 0.17$ & $16.28 \pm 0.16$ \\
EA & $202.86 \pm 14.64$ & $17.92 \pm 0.12$ \\
BuOH & $200 \pm 10.93$ & $46.76 \pm 0.36$
\end{tabular}

a: $\overline{m g}$ Gallic Acid Equivalent/g extract; ${ }^{\text {b }}$ mg Quercetin Equivalent/g extract. 


\subsection{Antioxidant Activities}

In the present work, the antioxidant activity was determined by five methods (Table 5). For $\beta$-carotene test, good activity was found in the three extracts $\left(\mathrm{IC}_{50}\right.$ value of $5.02 \pm 0.95,5.66 \pm 2.03$ and $7.60 \pm 4.37$ for dichloromethane, $n$-butanol and ethyl acetate, respectively), it was better than that of catechin $(8.79 \pm 0.89 \mu \mathrm{g} / \mathrm{mL})$ and higher of $\alpha$-tocopherol, BHT and quercetin $(2.10 \pm 0.08,1.34 \pm 0.04$ and $1.81 \pm 0.11 \mu \mathrm{g} / \mathrm{mL})$.

Table 5. Antioxidant activities of the three extracts of $H$. laevigata var. hipponensis.

\begin{tabular}{|c|c|c|c|c|c|}
\hline Extract & $\begin{array}{c}\beta \text {-Carotene } \\
\text { IC50 }(\mu \mathrm{g} / \mathrm{mL})\end{array}$ & $\begin{array}{c}\text { DPPH } \\
\text { IC50 }(\mu \mathrm{g} / \mathrm{mL})\end{array}$ & $\begin{array}{c}\text { ABTS+ } \\
\text { IC50 }(\mu \mathrm{g} / \mathrm{mL})\end{array}$ & $\begin{array}{c}\text { CUPRAC } \\
\text { A0.50 }(\mu \mathrm{g} / \mathrm{mL})\end{array}$ & $\begin{array}{l}\mathrm{Fe}^{+2} \text { Chelation } \\
\mathrm{IC}_{50}(\mu \mathrm{g} / \mathrm{mL})\end{array}$ \\
\hline Dichloromethane & $5.02 \pm 0.95$ & $47.24 \pm 0.11$ & $13.10 \pm 0.97$ & $16.86 \pm 3.02$ & $>800$ \\
\hline Ethyl acetate & $7.60 \pm 4.37$ & $8.70 \pm 1.87$ & $4.32 \pm 0.09$ & $1.48 \pm 0.33$ & $>800$ \\
\hline n-Butanol & $5.66 \pm 2.03$ & $8.12 \pm 1.47$ & $15.02 \pm 0.73$ & $3.00 \pm 0.98$ & $>800$ \\
\hline$(+)$-Catechin ${ }^{a}$ & $8.79 \pm 0.89$ & $4.32 \pm 0.15$ & $1.16 \pm 0.02$ & NT & NT \\
\hline Quercetin $^{\text {a }}$ & $1.81 \pm 0.11$ & $2.07 \pm 0.10$ & $1.18 \pm 0.03$ & NT & NT \\
\hline$\alpha$-Tocopherol ${ }^{\text {a }}$ & $2.10 \pm 0.08$ & $7.31 \pm 0.17$ & $4.31 \pm 0.10$ & $10.20 \pm 0.01$ & NT \\
\hline BHT $^{a}$ & $1.34 \pm 0.04$ & $45.4 \pm 0.47$ & $4.10 \pm 0.06$ & $3.80 \pm 0.00$ & NT \\
\hline EDTA $^{a}$ & NT & NT & NT & NT & $6.50 \pm 0.07$ \\
\hline Ascorbic acid ${ }^{a}$ & NT & NT & NT & NT & NT \\
\hline
\end{tabular}

For the DPPH test, maximum scavenging activity was found in $n$-butanol extract ( $\mathrm{IC}_{50}$ value: $8.12 \pm 1.47 \mu \mathrm{g} / \mathrm{mL}$ ) followed by ethyl acetate extract $\left(\mathrm{IC}_{50}\right.$ value: $\left.8.70 \pm 1.87 \mu \mathrm{g} / \mathrm{mL}\right)$. Dichloromethane extract showed a bit important activity $(47.24 \pm 0.11 \mu \mathrm{g} / \mathrm{mL})$. Studies reported that anti-radical activity is correlated with the level of polyphenols and flavonoids in medicinal plant extract [24-29].

In the ABTS+ method, the ethyl acetate extract(EA) exhibited the highest activity with an $\mathrm{IC}_{50}$ value of $4.32 \pm 0.09 \mu \mathrm{g} / \mathrm{mL}$ among all extract $\left(\mathrm{IC}_{50}\right.$ value of DCM extract $13.10 \pm 0.97$ and BuOH extract $15.02 \pm 0.73 \mu \mathrm{g} / \mathrm{mL})$ in comparison to $\alpha$-tocopherol and BHT $(4.31 \pm 0.10$ and $4.10 \pm 0.06 \mu \mathrm{g} / \mathrm{mL})$. The results proved that the extracts have the ability to trap the various free radicals in the different systems, indicating that they can be useful for therapeutic agents and for the treatment of radical-related pathological lesions [30].

Results of the CUPRAC test of $\mathrm{EA}$ and $\mathrm{BuOH}$ extracts exhibited a higher activity $\left(\mathrm{A}_{0.50}\right.$ value: $1.48 \pm 0.33$ and $3.00 \pm 0.98 \mu \mathrm{g} / \mathrm{mL}$, respectively) than those of standards (BHT with $3.80 \pm 0.00$ and $\alpha$-tocopherol with $10.20 \pm 0.01 \mu \mathrm{g} / \mathrm{mL}$ ). The results we found are similar to those of Gorinsteinet al. [31], who say that the highest capacities of polyphenolic compounds are measured with CUPRAC, and they are also similar to the results of Prior et al. [32], who found that the CUPRAC method showed the highest antioxidant activities compared with other antioxidants tests.

For the ferrous ions chelation test, all extracts were not active.

\section{Conclusions}

This study was performed to investigate the chemical composition of phenolic compounds in dichloromethane, ethyl acetate, and $n$-butanol extracts of H. laevigata var. hipponensis by the liquid chromatography-mass spectrometry (LC-MS/MS) technique. The LC-MS/MS lead a total of 23 chemical compounds in the three extracts (EA with 20 compounds, $\mathrm{BuOH}$ with 15 compounds, and DCM with nine compounds). Chlorogenic acid, caffeic acid, ferulic acid, $p$-coumaric acid, syringic acid, and 4-OH-benzoic were the major phenolic compounds detected. The total phenolic contents indicated that EA fraction and $\mathrm{BuOH}$ presented the highest value. The flavonoid content showed that $\mathrm{BuOH}$ exhibited the highest value. The antioxidant activities of the tested extracts showed a positive result with the $\beta$-carotene bleaching method, DPPH radical scavenging activity, ABTS cation radical scavenging 
activity, and cupric reducing antioxidant capacity. However, the ferrous iron chelation assay showed a negative result. When we compared the antioxidant activities of the three extracts, we found that the ethyl acetate extract was more potent than the n-butanol and dichloromethane extracts. Finally, we recommend the continuation our work in the future to evaluate more biological activities in vitro and in vivo, and to isolate the chemical compounds of the plant.

Author Contributions: N.S. contribution to investigation, data curation, and writing the original draft; S.A. contribution to supervision, Software; Z.U. and M.Ö. contribution to methodology and project administration; N.S. and K.M. contribution to resources and writing-review; H.B. contribution to visualization; T.H. contribution to resources; N.S. and G.N. and T.H. contribution to conceptualization, data curation, supervision, resources and writing-review. All authors have read and agreed to the published version of the manuscript.

Funding: Supported by the National Fund for Scientific Research, PRFU Projects, Ministry of Higher Education and Scientific Research, Algeria (Code N: B00L01UN250120180010).

Acknowledgments: The authors are grateful to the General Direction of Scientific Research of Algeria (DGRSDT) and both the Department of Chemistry in University of Mugla (Turkey) for providing funds to perform the present research.

Conflicts of Interest: The authors declare that there are no conflicts of interest.

\section{References}

1. Hamel, T. Contribution à l'étude de l'endémisme chez les végétaux vasculaires dans la péninsule de l'Edough (Nord-Est algérien). Ph.D. Thesis, Université Badji Mokhtar, Annaba, Algérie, 2013. Available online: https://www.researchgate.net/publication/319310678 (accessed on 14 February 2020). [CrossRef]

2. Stebbins, G.L. Chromosomal changes, genetic recombination and speciation. In Chromosomal Evolution in Higher Plants; Arnold, E., Ed.; Edward Arnold: London, UK, 1971; pp. 107-111.

3. Quézel, P.; Santa, S. Nouvelle Flore d'Algérie et des Régions Désertiques Méridionales; 2 Tomes, Editions; CNRS: Paris, France, 1962; 1170p.

4. Jamuna, S.; Paulsamy, S.; Karthika, K. Phytochemical analysis and evaluation of leaf and root parts of the medicinal herb, Hypochaeris radicata L. for in vitro antioxidant activities. Asian Pac. J. Tro. Bio. 2014, 4, S359-S367.

5. Jamuna, S.; Paulsamy, S.; Karthika, K. Screening of in vitro antioxidant activity of methanolic leaf and root extracts of Hypochaeris radicata L. (Asteraceae). J. Appl. Pharm. Sci. 2012, 2, 149-154. [CrossRef]

6. Jamuna, S.; Paulsamy, S.; Karthika, K. In vitro antibacterial activity of leaf and root extracts of Hypochaeris radicata L. (Asteraceae): A medicinal plants pecies in habiting the high hills of Nilgiris, the Western Ghats. Int. J. Pharm. Pharm. Sci. 2013, 5, 175-178.

7. Jamuna, S.; Paulsamy, S.; Karthika, K. In vitro antifungal activity of leaf and root extracts of the medicinal plant, Hypochaeris radicata L. Int. J. Pharm. Pharm. Sci. 2013, 5, 758-761.

8. Pullaiah, T. Encyclopedia of World Medicinal Plants; Regency publication: New Delhi, India, 2006; pp. 1-525.

9. Li, R.; Guo, M.; Zhang, G.; Xu, X.; Li, K. Neuroprotection of Nicotiflorin in Permanent Focal CerebralIschemia and in Neuronal Cultures. Biol. Pharm. Bull. 2007, 29, 1868-1872. [CrossRef]

10. Djeridane, A.; Yousfi, M.; Nadjemi, B.; Boutassouna, D.; Stocker, P.; Vidal, N. Antioxidant activity of some Algerian medicinal plants extracts containing phenolic compounds. Food. Chem. 2006, 97, 654-660. [CrossRef]

11. Miller, E.D. Isolation and characterization of the cyanogenbromide peptides from the alpha. 1 (II) chain of chick cartilage collagen. Biochemistry 1971, 10, 3030-3035. [CrossRef]

12. Blois, M.S. Antioxidant Determinations by the Use of a Stable Free Radical. Int. J. Sci. Nat. 1958, 181, 1199-1200. [CrossRef]

13. Scherer, R.; Godoy, H.T. Antioxidant activity index (AAI) by the 2,2-diphenyl-1-picrylhydrazyl method. Food Chem. 2009, 112, 654-658. [CrossRef]

14. Maisuthisakul, P.; Suttajit, M.; Pongsawatmanit, R. Assessment of phenolic content and free radical-scavenging capacity of some Thai indigenous plants. Food Chem. 2007, 100, 1409-1418. [CrossRef]

15. Re, R.; Pellegrini, N.; Proteggente, A.; Pannala, A.; Yang, M.; Rice-Evans, C. Antioxidant activity applying an improved ABTS radical cation decolorization assay. Free Radic. Bio. Med. 1999, 26, 1231-1237. [CrossRef] 
16. Apak, R.; Güçlü, K.; Özyürek, M.; Karademir, S.E. Novel total antioxidant capacity index for dietary polyphenols and vitamins $\mathrm{C}$ and $\mathrm{E}$, using their cupric ion reducing capability in the presence of neocuproine: CUPRAC Method. J. Agric. Food Chem. 2004, 52, 7970-7981. [CrossRef] [PubMed]

17. Decker, E.A.; Welch, B. Roleof ferritin as a lipid oxidation catalystin muscle food. J. Agric. Food Chem. 1990, 38, 674-677. [CrossRef]

18. Heleno, S.A.; Martins, A.; Queiroz, M.J.R.; Ferreira, I.C. Bioactivity of phenolic acids: Metabolites versusparent compounds: A review. Food Chem. 2015, 173, 501-513. [CrossRef]

19. Hur, J.Y.; Soh, Y.; Kim, B.-H.; Suk, K.; Sohn, N.W.; Kim, H.C.; Kwon, H.C.; Lee, K.R.; Kim, S.Y. Neuroprotective and Neurotrophic Effects of Quinic Acids from Asterscaberin PC12Cells. Biol. Pharm. Bull. 2001, 24, 921-924. [CrossRef]

20. Tapas, A.R.; Sakarkar, D.M.; Kakde, R.B. Flavonoids as nutraceuticals: A review. Trop. J. Pharm. Res. 2008, 7, 1089-1099. [CrossRef]

21. Tripoli, E.; LaGuardia, M.; Giammanco, S.; DiMajo, D.; Giammanco, M. Citrus flavonoids: Molecular structure, biological activity and nutritional properties: A review. Food Chem. 2007, 104, 466-479. [CrossRef]

22. Tsolmon, S.; Nakazaki, E.; Han, J.; Isoda, H. Apigetrin induces erythroid differentiation of human leukemia cells K562: Proteomics approach. Mol. Nutr. Food Res. 2011, 55, S93-S102. [CrossRef]

23. Rao, Y.K.; Lee, M.J.; Chen, K.; Lee, Y.-C.; Wu, W.-S.; Tzeng, Y.-M. Insulin-Mimetic Action of Rhoifolin and Cosmosiin Isolated from Citrus grandis (L.) Osbeck Leaves: Enhanced Adiponectin Secretion and Insulin Receptor Phosphorylation in 3T3-L1 Cells. Evid. Based Complementary Altern. Med. 2011, 2011, 624375. [CrossRef]

24. Mariod, A.A.; Ibrahim, R.M.; Ismail, M.; Ismail, N. Antioxidant activity and phenolic content of phenolic rich fractions obtained from black cumin (Nigella sativa) seed cake. Food Chem. 2009, 116, 306-312. [CrossRef]

25. Martinez, J.; Nieto, G.; Castillo, J.; Ros, G. Influence of in vitro gastrointestinal digestion and/ orgrape seed extract addition on antioxidant capacity of meatemul-sions. Lebensmittel-Wissenschaftund-Technologie LWT 2014, 59, 834-840. [CrossRef]

26. Nieto, G.; Bañon, S.; Garrido, M.D. Incorporation of thyme leaves in the diet of pregnant and lactating ewes: Effect on the fatty acid profile of lamb. Small Rum. Res. 2012, 105, 140-147. [CrossRef]

27. Nieto, G.; Bañon, S.; Garrido, M.D. Administration of distillate thyme leaves in to the diet of Segureña ewes: Effect on lambme at quality. Animal 2012, 6, 2048-2056. [CrossRef] [PubMed]

28. Nieto, G. Incorporation of by- products of rosemary and thyme in the diet of ewes: Effect on the fatty acid profile of lamb. Eur. Food Res. Technol. 2013, 236, 379-389. [CrossRef]

29. Martínez, L.; Jongberg, S.; Ros, G.; Skibsted, L.H.; Nieto, G. Plant derived ingredients rich in nitrates or phenolics for protection of pork against protein oxidation. Food Res. Int. 2020, 129, 108789. [CrossRef]

30. Wang, M.; Li, J.; Rangarajan, M.; Shao, Y.; LaVoie, E.J.; Huang, T.-C.; Ho, C.-T. Antioxidative phenolic compounds from sage (Salvia officinalis). J. Agric. Food Chem. 1998, 46, 4869-4873. [CrossRef]

31. Gorinstein, S.; Leontowicz, M.; Leontowicz, H.; Najman, K.; Namiesnik, J.; Park, Y.-S.; Jung, S.-T.; Kang, S.-G.; Trakhtenberg, S. Supplementation of garlic lowers lipids and increases antioxidant capacity in plasma of rats. Nutr. Res. 2006, 26, 362-368. [CrossRef]

32. Prior, R.L.; Wu, X.; Schaich, K. Standardized methods for the determination of antioxidant capacity and phenolics in foods and dietary supplements. J. Agric. Food Chem. 2005, 53, 4290-4302. [CrossRef]

(C) 2020 by the authors. Licensee MDPI, Basel, Switzerland. This article is an open access article distributed under the terms and conditions of the Creative Commons Attribution (CC BY) license (http://creativecommons.org/licenses/by/4.0/). 